\title{
Incorporation of the e - Government as a transversal axis in the Local Development Plans
}

\author{
Israel Patiño Galván \\ Research Division of the Innovation Park - PILS, \\ University La Salle Northwest, Mexico;
}

\begin{abstract}
E-government is part of the international mechanisms and initiatives for the proper use of information and communication technologies by governments in order to collaborate in the generation of information, Decision making, transparency and optimization of processes. However, local governments have problems in their implementation, use and exploitation, which limits their performance and sustainable impact. Therefore, a transversal axis in the Local Development Plans is proposed about e-government, and with this, collaborate for the satisfactory implementation of the Information and Communication Technologies.
\end{abstract}

KEYWORDS: Electronic government, municipal development plan, Transversal axis, Information and communication technologies

\section{INTRODUCTION}

The Local Development Plans (LDP) are documents that reflect the priorities, goals, commitments and mechanisms that express the agreements of the communities and citizens organized with their municipalities, which are permanently contextualizing the needs and services that citizens require., in addition to aligning with the State and National Development Plans. In addition to seeking mechanisms for optimization, and the use of Information and Communication Technologies (ICT), it was found that most of the municipalities lack the use of such technologies through e-Government as a central axis. Therefore, in this article, a search is made in a sample of municipalities, progress in the implementation of ICT in the context of national and international local governments, and most of these technologies are not used, nor are they There is an infrastructure that can provide support so that future administrations can follow up, and not to mention the follow-up of projects where electronic government is involved as a transversal axis. So, based on this framework of ideas, and accompanied by research methodologies, conceptual and contextual analysis of the LDP, a proposal is made to contemplate a vertical axis of electronic government and 13 strategies linked to this axis.

\section{RESEARCH METHODOLOGY}

This document is supported by the analysis and synthesis research methods (Fernández, Nares, \& Garcia, 2008). Since it allowed the segmented study of each municipality and its characteristics, to later join them and identify their relationships, similarities, differences and common characteristics. Field research was used (Hernández Sampieri, Fernández Collado, \& Baptista Lucio, 1997). Through the survey and questionnaire applied to administrative staff of the municipal governments shows, in order to obtain information that will indicate the current conditions of the subjects and object of study. In addition to using documentary research in order to obtain information on experiences of local governments in some countries of America in the incorporation of electronic government as a transversal axis in the Local Development Plans. 


\section{CONCEPT AND CONTEXT OF ELECTRONIC GOVERNMENT}

E-government refers to the use of information technology and communications by the public sector with the aim of improving the provision of information and public service. In this sense, citizen participation is stimulated in the decision-making process, making the government more responsible, transparent and efficient (Ruiz, Morales, \& Contreras, 2014). In addition, it is important to identify the stages that governments go through, in the process of identification and implementation of information and communication technologies, to then present their evolution and stages of electronic government (United Nations, 2016). These stages are nonhierarchical, that is, it is not necessary for one end to anticipate the other, they regularly evolve, as the complexity of the systems increases, where they are associated with technological developments and tools (ICT) are incorporated for governance., where the whole society benefits (Pérez, Camacho, Mena, \& Arroyo , 2016), the levels are:

- $\quad$ Stage 1. Emergent or basic

- Stage 2. Interaction

- Stage 3. Transaction

- Stage 4. Connected or processing

- Stage 5. Integrated process

While the United Nations (ONU, 2014) briefly describes every four stages of evolution, which are conceptualized below:

- Stage 1 Emerging information services. Government websites provide information on public policies, government, laws, regulations, relevant documentation and types of government services provided.

- Stage 2 Improved information services. Government websites offer enhanced unidirectional or bidirectional electronic communications between government and citizen, such as downloadable forms for government services and applications.

- Stage 3 Transactional services. Government websites participate in bidirectional communication with their citizens, which includes requesting and receiving information about government policies, programs, regulations, etc. Some form of electronic authentication of the identity of the citizen is required to successfully complete the exchange.

- Stage 4. Connected services. Government websites have changed the way governments communicate with their citizens. They are proactive in requesting information and opinions from citizens who use Web 2.0 and other interactive tools.

\section{Indicators of electronic government}

To carry out this research and analyze the development in the implementation of electronic government, a documentary study was carried out on the indicators suggested by the UN (2014), which help to evaluate progress in the implementation of information technology in government. However, these are not evident in local governments, which gave rise to this research and proposal. The components of the indicators suggested by the (ONU, 2014) for electronic government are shown below

- Online services organization index

- Telecommunications infrastructure index

- Human capital index

As can be seen, there are 3 main indices, which makes electronic government integral. In order to identify each component of the indexes, its detail is presented below (ONU, 2014):

- Online services organization index

- Close the digital divide, Open Government

○ Multichannel service delivery, Increase in use 
- Telecommunications infrastructure index

- Subscriptions of mobile phones

- Fixed telephone subscriptions

- Percentage of people who use the internet

- Fixed broadband for every 100

- Wireless broadband for every 100

- Human capital index

- Years of schooling expected

- Average year of schooling

- Percentage of adult literacy

It is important to consider that the Human Capital Index takes questionnaires, which are organized into specific topics structured into four themes, corresponding to the four stages of the development of electronic government.

\section{NORMATIVE CONTEXT OF LOCAL DEVELOPMENT PLANS IN MEXICO}

Planning the development in the Municipality means, applying with objectives clearly, goals and priorities; it defines actions and allocate resources based on the type of development to which the local community aspires. Conceived in this way, planning is a rational and systematic process through which the inhabitants of the Municipality and its authorities: Identify, diagnose their problems and needs, as well as the actual and potential resources with which they have the purpose of analyzing and present the development proposals. They establish priorities and goals, in addition to commitments and co-responsibility mechanisms in a timely manner. It can also be defined as the guiding instrument for the integral development of the Municipality, a fundamental result of the planning process that is generated and established at the municipal level. It expresses the agreement of wills and agreements of communities and citizens organized with their municipalities, and coordination mechanisms with the state and federal levels. From these considerations, the planning of the development is not only a matter of specialists, but, above all, a process of convergence of knowledge, techniques, abilities, capacities and political visions, and integrating research and innovation in the field that corresponds to it., in constant reworking to transform reality. The planning of municipal development is based on the following legal systems: Political Constitution of the United Mexican States, Planning Law, State Constitution, State Planning Law and Municipal Organic Law (INAFED, 2004)

Table 1. Legal and programmatic framework of the Municipality

\begin{tabular}{|c|c|c|}
\hline $\begin{array}{l}\text { National System of } \\
\text { Democratic Planning }\end{array}$ & $\begin{array}{l}\text { National Plan } \\
\text { developmental }\end{array}$ & $\begin{array}{l}\text { - Political constitution } \\
\text { - Planning Law } \\
\text { - Organic Law of the Federal Public } \\
\text { Administration }\end{array}$ \\
\hline $\begin{array}{l}\text { COPLADE Citizen } \\
\text { participation - Systems State } \\
\text { Planning Democratic }\end{array}$ & $\begin{array}{l}\text { State Plan } \\
\text { developmental }\end{array}$ & $\begin{array}{l}\text { - Political constitution } \\
\text { - State Legislations } \\
\text { - Organic Law of the State Public } \\
\text { Administration }\end{array}$ \\
\hline $\begin{array}{l}\text { COPLADEMUN Participation } \\
\text { citizen - Systems Municipal } \\
\text { Planning Democratic }\end{array}$ & $\begin{array}{l}\text { Municipal Plan } \\
\text { developmental }\end{array}$ & $\begin{array}{l}\text { - Article } 115 \text { Constitutional } \\
\text { - Local laws } \\
\text { - Municipal Organic Law } \\
\end{array}$ \\
\hline
\end{tabular}

Source: Guide for good municipal government, INAFED (2004), p. 12

\section{INCORPORATION OF ELECTRONIC GOVERNMENT AS A TRANSVERSAL AXIS IN THE LOCAL DEVELOPMENT PLANS IN AMERICA}

For the purposes of this research, was taked some municipality of the countries of Argentina, Colombia, Costa Rica and Canada will be randomly selected from three provinces, whose 
municipal development plans are intertwined between 2015 and 2017. In addition to identifying the hierarchical level assigns them to activities related to electronic or related government

Table 2. Local development plans consulted from America

\begin{tabular}{|c|c|c|c|c|}
\hline \multirow[t]{2}{*}{ Country } & \multirow{2}{*}{$\begin{array}{l}\text { Municipality / } \\
\text { Province }\end{array}$} & \multicolumn{3}{|c|}{ Concept } \\
\hline & & $\begin{array}{c}\text { Transverse } \\
\text { axis }\end{array}$ & Objective & Specific goal \\
\hline Argentina & Concepción & & $\begin{array}{l}\text { Digital } \\
\text { connectivity }\end{array}$ & \\
\hline Colombia & $\begin{array}{l}\text { Cartagena de } \\
\text { Indias }\end{array}$ & & & $\begin{array}{l}\text { Science, Technology and } \\
\text { Innovation Program - ICT }\end{array}$ \\
\hline Colombia & Medellín & & & $\begin{array}{l}\text { Building trust with } \\
\text { government online }\end{array}$ \\
\hline Costa Rica & San Jose & & & $\begin{array}{l}\text { Digital / electronic } \\
\text { government }\end{array}$ \\
\hline Canada & $\begin{array}{l}\text { Nanaimo / British } \\
\text { Columbia / Ottawa }\end{array}$ & $\begin{array}{l}\text { Information } \\
\text { technology }\end{array}$ & & \\
\hline
\end{tabular}

Source: Argentina: Municipal Development Plan of Concepción de Buenos Aires, Jal. 2015-2018; Colombia: First people development plan 2016 - 2019, mayor of Cartagena de Indias; Colombia: Medellín Development Plan 2016-2019; Costa Rica: Municipality of San José, Municipal Development Plan 2017-2020; Canada: Strategic Plan 2012 to 2015 City of Nanaimo, Province of British Columbia Strategic Plan 2017 / 2018-20202021, City of Ottawa 2015-2018 Strategic Plan.

In the case of the local government of Concepción in Argentina, it focuses on the maintenance of Digital Community Centers or CCDs that are installed in the federal program, which consist of bringing Information and Communication Technologies (ICT) closer to social contexts, in order to ensure that the population has access to these tools in their daily activities, through spaces with the basic infrastructure for information consultation (Concepción de Buenos Aires, 2015). Although this is an advance in the incorporation of ICT in the Electronic Government services, it lacks a transversal scope where these Technologies are implemented in the administrative and operational activities and processes inside and outside the government.

While, in Cartagena de Indias in Colombia, a "Science, Technology and Innovation - ICT program" is included, which is anchored to a strategic line, related to investments, as shown below:

3. Second part: strategic component

3.1. Top objective of the development plan "welfare of the people"

3.1.2. Strategic objective 2: adapt the territory for the people

3.1.2.1. Strategic axis 1: inclusive economic development

3.1.2.1.1. Strategic line 1: Cartagena city to invest

3.1.2.1.4. Science, Technology and Innovation Program - ICT

The purpose of this program is to support initiatives that strengthen the University - Company - State, relationship as a strategy to promote technological development and innovation, boosting the productivity and competitiveness of the locality, positively impacting the competitiveness factors of the city (Alcaldía de Cartagena de indias, 2016). Although it collaborates with one of the fundamental axes such as the economic, it lacks the use of ICT in the administrative and operational processes of the government, in order to address crosscutting services to citizens. 
According to the Medellin Development Plan 2016-2019, a project named "Building trust with online government" is contemplated, in which this project aims to improve the relationship between local government and citizens, through the implementation of procedures and services through electronic channels and the mass use of tools. In addition to facilitating means of participation in the construction of a transparent, participatory and collaborative administration (Medellín, 2016). This project is established in the following index of the Development Plan:

1. Strategic part

1.3 well-managed Medellin

1.3.2 Program: transparency as a management model

1.3.2.2 Project: Building trust with government online

This program in accordance with the indicators and evolution of electronic government indicated by the United Nations (ONU, 2014) have a significant progress, however it lacks clarity regarding the internal and external processes of the local administration, as well as its cross-cutting intervention within and outside of the administration.

On the other hand, in the local government of San Jose, Costa Rica includes two items, the first on "Electronic Government" and the second "integrated information system for municipal management" both are linked to a main axis called "municipal management" intelligent and with leadership " (Municipalidad de San José, 2017). Of both items, the most complete and oriented to electronic government suggested by the United Nations (ONU, 2014) is the item with the same name (electronic government) that has the following goals:

- Update of a technological renovation plan in the institution

- Annual implementation of the technology renewal plan for updating corporate licenses and equipment

- Design and implementation of 4 online municipal services: land uses, construction permits, commercial licenses, urban services

- Complete the project of the Urban Identity Card of the Property

- Implementation of the open data application on the municipal website

As can be seen, different operational and administrative strategies are observed for the use and optimization of processes, however, like the other municipalities analyzed, e-government is not identified as a transversal axis.

For the municipalities previously analyzed, it does not mean that the implementation and operation of electronic government is bad, which lacks this as a transversal strategy. However, it understands that it is a process of gradual incorporation, so these local governments are in the initial stages, where it is expected that with the passage of administrations these can be accelerated so that the use of the information and communication technologies.

In the case of Canada, in Nanaimo / British Columbia / Ottawa there is the National Strategic Plan of Information Technologies of the Government of Canada 2016-2020 (Government of Canada, 2018), which is taken as a basis for the strategic plans of the Government of Canada. local governments, which facilitates the alignment of objectives and their compliance. This is without considering the context of the local and regional governments of that country, where the asymmetry in the physical infrastructure, human resources and visions of the governments influence in their development and successful implementation of the Information and Communication Technologies in the processes administrative and operational, inside and outside of the local governments in question. 


\section{RESULTS AND INTERPRETATION OF THE FIELD RESEARCH APPLICATION: CASE OF MEXICO}

\section{Determination of the sample}

For the determination of the sample, the population type was analyzed, which was integrated by the 2,456 municipalities of the Mexican Republic according to it INEGI (INEGI, 2015), and to take a significant sample, simple stratified sampling and qualitative analyzes were used. (variables) such as:

- Gross domestic product

- Total population

- Average grade level

- Housing with Internet

Once the variables and the technique for determining the sample were defined, the calculation was performed.

Formula (Equation 1):

$$
n=\frac{Z^{2} p q N}{N E^{2}+Z^{2} p q}
$$

Where:

$\mathrm{n}=$ Theoretical amount of sample elements (?)

$\mathrm{Z}=$ Reliability (1.96)

$\mathrm{p}=$ Percentage that meets the characteristics of the population $(93 \%)$

$q=$ Percentage that does not meet the characteristics of the population (7\%)

$\mathrm{N}=$ Population (2, 456 Municipalities in Mexico)

$\mathrm{E}=$ Error assumed (5\%)

Substituting values in the equation (Equation 2):

$$
n=\frac{(1.96)^{2} *(0.93 * 0.07) * 2456}{\left(2456 *(0.05)^{2}\right)+(2456)^{2} *(0.93) *(0.07)}=96.12
$$

The sample to be studied is of 96 municipalities (rounding off) throughout the Mexican Republic. After finding the number of samples, an analysis of the variables was carried out, to include in the study the participation of all the States of the Mexican Republic and 3 municipalities of each one. For this, Table 3 is presented in which the analysis is shown. 
Table 3. Analysis of variables by municipality to determine the selection of samples

\begin{tabular}{|c|c|c|c|c|}
\hline No. & State & $\begin{array}{c}\text { Number of } \\
\text { Municipality }\end{array}$ & $\begin{array}{c}\text { Relative } \\
\text { Frequency }\end{array}$ & $\begin{array}{l}\text { Relative cumulative } \\
\text { frequency }\end{array}$ \\
\hline 1 & Aguascalientes & 11 & $0.45 \%$ & $0.45 \%$ \\
\hline 2 & Baja California & 5 & $0.20 \%$ & $0.65 \%$ \\
\hline 3 & Baja California Sur & 5 & $0.20 \%$ & $0.86 \%$ \\
\hline 4 & Campeche & 11 & $0.45 \%$ & $1.30 \%$ \\
\hline 5 & Chiapas & 118 & $4.80 \%$ & $6.11 \%$ \\
\hline 6 & Chihuahua & 67 & $2.73 \%$ & $8.84 \%$ \\
\hline 7 & Ciudad de México & 16 & $0.65 \%$ & $9.49 \%$ \\
\hline 8 & Coahuila & 38 & $1.55 \%$ & $11.03 \%$ \\
\hline 9 & Colima & 10 & $0.41 \%$ & $11.44 \%$ \\
\hline 10 & Durango & 39 & $1.59 \%$ & $13.03 \%$ \\
\hline 11 & Estado de México & 125 & $5.09 \%$ & $18.12 \%$ \\
\hline 12 & Guanajuato & 46 & $1.87 \%$ & $19.99 \%$ \\
\hline 13 & Guerrero & 81 & $3.30 \%$ & $23.29 \%$ \\
\hline 14 & Hidalgo & 84 & $3.42 \%$ & $26.71 \%$ \\
\hline 15 & Jalisco & 125 & $5.09 \%$ & $31.80 \%$ \\
\hline 16 & Michoacán & 113 & $4.60 \%$ & $36.40 \%$ \\
\hline 17 & Morelos & 33 & $1.34 \%$ & $37.74 \%$ \\
\hline 18 & Nayarit & 20 & $0.81 \%$ & $38.56 \%$ \\
\hline 19 & Nuevo León & 51 & $2.08 \%$ & $40.64 \%$ \\
\hline 20 & Oaxaca & 570 & $23.21 \%$ & $63.84 \%$ \\
\hline 21 & Puebla & 217 & $8.84 \%$ & $72.68 \%$ \\
\hline 22 & Querétaro & 18 & $0.73 \%$ & $73.41 \%$ \\
\hline 23 & Quintana Roo & 9 & $0.37 \%$ & $73.78 \%$ \\
\hline 24 & San Luis Potosí & 58 & $2.36 \%$ & $76.14 \%$ \\
\hline 25 & Sinaloa & 18 & $0.73 \%$ & $76.87 \%$ \\
\hline 26 & Sonora & 72 & $2.93 \%$ & $79.80 \%$ \\
\hline 27 & Tabasco & 17 & $0.69 \%$ & $80.50 \%$ \\
\hline 28 & Tamaulipas & 43 & $1.75 \%$ & $82.25 \%$ \\
\hline 29 & Tlaxcala & 60 & $2.44 \%$ & $84.69 \%$ \\
\hline 30 & Veracruz & 212 & $8.63 \%$ & $93.32 \%$ \\
\hline 31 & Yucatán & 106 & $4.32 \%$ & $97.64 \%$ \\
\hline 32 & Zacatecas & 58 & $2.36 \%$ & $100.00 \%$ \\
\hline \multicolumn{2}{|r|}{ Total } & 2456 & $100.00 \%$ & \multirow{2}{*}{ 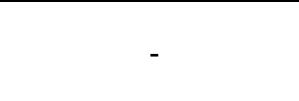 } \\
\hline \multicolumn{2}{|c|}{ Municipally Average } & 76.75 & 3 & \\
\hline
\end{tabular}

\section{Source: Own elaboration (2017)}

Once the segmentation is done, and considering the variables, it is confirmed that the sample is 96, taking three municipalities from each state of the Mexican Republic. The selected municipalities were (See Table 4): 
Table 4. Sample selection

\begin{tabular}{|c|c|c|c|c|c|}
\hline No & State & Municipality & No & State & Municipality \\
\hline 1 & \multirow{3}{*}{ Aguascalientes } & San José de Gracia & 49 & \multirow{3}{*}{ Morelos } & Tlalnepantla \\
\hline 2 & & Asientos & 50 & & Jantetelco \\
\hline 3 & & Aguascalientes & 51 & & Cuernavaca \\
\hline 4 & \multirow{3}{*}{ Baja California } & Playas de Rosarito & 52 & \multirow{3}{*}{ Nayarit } & Del Nayar \\
\hline 5 & & Ensenada & 53 & & San Pedro Lagunillas \\
\hline 6 & & Tijuana & 54 & & Tepic \\
\hline 7 & \multirow{3}{*}{$\begin{array}{c}\text { Baja California } \\
\text { Sur }\end{array}$} & Comondú & 55 & \multirow{3}{*}{ Nuevo León } & Mier y Noriega \\
\hline 8 & & Mulegé & 56 & & Melchor Ocampo \\
\hline 9 & & La Paz & 57 & & San Pedro Garza García \\
\hline 10 & \multirow{3}{*}{ Campeche } & Calakmul & 58 & \multirow{3}{*}{ Oaxaca } & Asunción Tlacolulita \\
\hline 11 & & Champotón & 59 & & Villa de Chilapa de Díaz \\
\hline 12 & & Campeche & 60 & & San Sebastián Tutla \\
\hline 13 & \multirow{3}{*}{ Coahuila } & Escobedo & 61 & \multirow{3}{*}{ Puebla } & Ahuatlán \\
\hline 14 & & Matamoros & 62 & & Tepeojuma \\
\hline 15 & & Monclova & 63 & & San Andrés Cholula \\
\hline 16 & \multirow{3}{*}{ Colima } & Ixtlahuacán & 64 & \multirow{3}{*}{ Querétaro } & Landa de Matamoros \\
\hline 17 & & Coquimatlán & 65 & & Huimilpan \\
\hline 18 & & Villa de Álvarez & 66 & & Corregidora \\
\hline 19 & \multirow{3}{*}{ Chiapas } & Sunuapa & 67 & \multirow{3}{*}{ Quintana Roo } & José María Morelos \\
\hline 20 & & Tzimol & 68 & & Tulum \\
\hline 21 & & Tuxtla Gutiérrez & 69 & & Cozumel \\
\hline 22 & \multirow{3}{*}{ Chihuahua } & Huejotitán & 70 & \multirow{3}{*}{$\begin{array}{l}\text { San Luis } \\
\text { Potosí }\end{array}$} & Santa Catarina \\
\hline 23 & & San Francisco de Conchos & 71 & & Ciudad del Maíz \\
\hline 24 & & Chihuahua & 72 & & San Luis Potosí \\
\hline 25 & \multirow{3}{*}{ Ciudad de México } & Milpa Alta & 73 & \multirow{3}{*}{ Sinaloa } & Badiraguato \\
\hline 26 & & La Magdalena Contreras & 74 & & Navolato \\
\hline 27 & & Benito Juárez & 75 & & Culiacán \\
\hline 28 & \multirow{3}{*}{ Durango } & San Pedro del Gallo & 76 & \multirow{3}{*}{ Sonora } & Onavas \\
\hline 29 & & Pánuco de Coronado & 77 & & Etchojoa \\
\hline 30 & & Durango & 78 & & Hermosillo \\
\hline 31 & \multirow{3}{*}{ Guanajuato } & Atarjea & 79 & \multirow{3}{*}{ Tabasco } & Jonuta \\
\hline 32 & & Apaseo el Alto & 80 & & Teapa \\
\hline 33 & & Guanajuato & 81 & & Centro \\
\hline 34 & & Tlacoapa & 82 & & San Nicolás \\
\hline 35 & Guerrero & Leonardo Bravo & 83 & Tamaulipas & Antiguo Morelos \\
\hline 36 & & Chilpancingo de los Bravo & 84 & & Ciudad Madero \\
\hline 37 & & Juárez Hidalgo & 85 & & Españita \\
\hline 38 & Hidalgo & Mineral del Chico & 86 & Tlaxcala & Contla de Juan Cuamatzi \\
\hline 39 & & Pachuca de Soto & 87 & & Tlaxcala \\
\hline 40 & & Tuxcacuesco & 88 & & Aquila \\
\hline 41 & Jalisco & Teocaltiche & 89 & Veracruz & Manlio Fabio Altamirano \\
\hline 42 & & Zapopan & 90 & & Boca del Río \\
\hline 43 & & San José del Rincón & 91 & & Chacsinkín \\
\hline 44 & Estado de México & Ayapango & 92 & Yucatán & Santa Elena \\
\hline 45 & & Metepec & 93 & & Mérida \\
\hline 46 & & Tzitzio & 94 & & Melchor Ocampo \\
\hline 47 & Michoacán & Gabriel Zamora & 95 & Zacatecas & Apozol \\
\hline 48 & & Morelia & 96 & & Zacatecas \\
\hline
\end{tabular}




\section{Results and interpretation of the field research application}

Derived from the design of the instrument, application of pilot tests and its congruence matrix, the following questions and answers applied to the 96 selected municipalities are addressed, addressed to administrative staff of said municipalities. The following result was found.

A. What municipalities in Mexico contemplate electronic government or related issues as a transversal axis in the Municipal Development Plan?

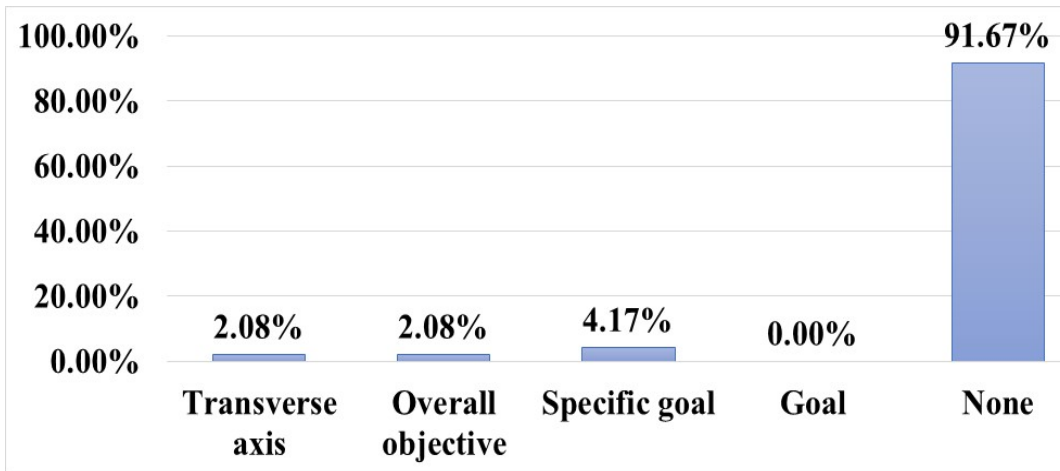

Source: Information consulted in the municipal development plans of the 96 municipalities. Said plans consulted corresponded to the three-year periods immersed between 2015, 2016 and 2017.

The municipalities that come close to the definition of electronic government, as a transversal axis represent $2.08 \%$ of the total, these are: Aguascalientes of the state of Aguascalientes and the municipality of Pachuca de Soto of the State of Hidalgo. While 91.67\% of the rest of the municipalities do not include it. What collaborates to give foundation to the proposal of the present article. On the other hand, the results of the application of the instrument are presented below.

Question 1. What development plan do you use as a reference for the development of the Municipal Development Plan?

b) State Development Plan

a) National Development Plan

c) The previous two

d) None

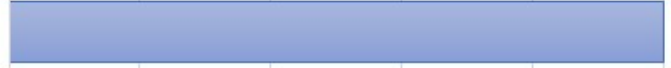

$\mathbf{5 0 . 0 0 \%}$ $10.00 \%$

$0.00 \%$

Source: Results of the application of the instrument to administrative staff at the hierarchical level of management or sub-direction (2017).

As can be seen, $90 \%$ of the municipalities take as reference the National Development Plan $(40 \%)$ and the State Development Plan (50\%) and the rest consult both plans. With this, it can be concluded that the congruence between the federal, state and municipal levels continues. 
Question 2. In which normative framework consultations as, additional inputs for the preparation of the local development plan.

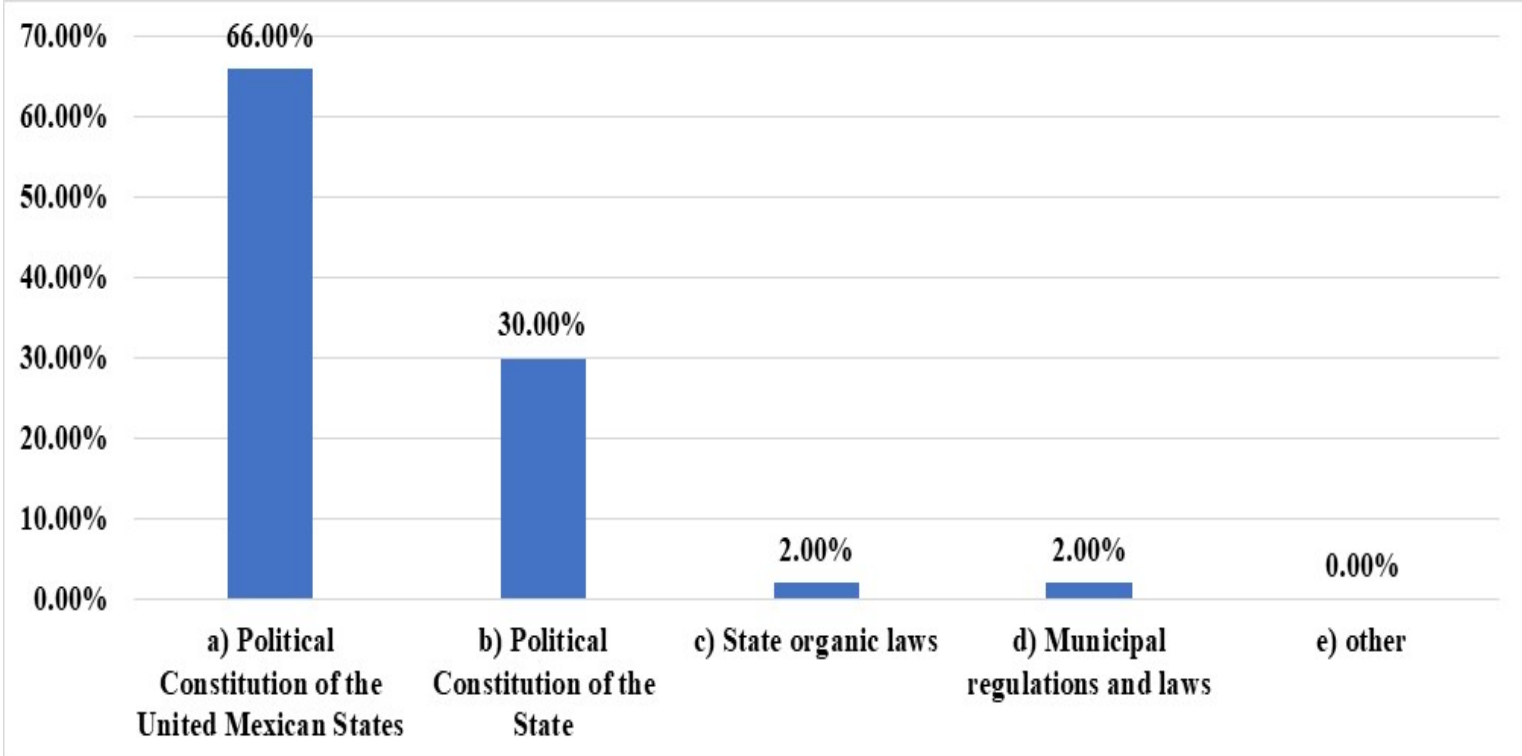

Source: Results of the application of the instrument to administrative staff at the hierarchical level of management or sub-direction (2017).

According to the results, more than $96 \%$ of the municipalities consult the political constitution of the United Mexican States (66\%) and the constitution corresponding to the state where they belong (30\%). With this, the foundation is achieved, as well as the functions transferred to it by the national and state constitutions.

Question 3. You take into consideration some of the recommendations of the following organizations in relation to the incorporation and use of Information Technologies in public administration

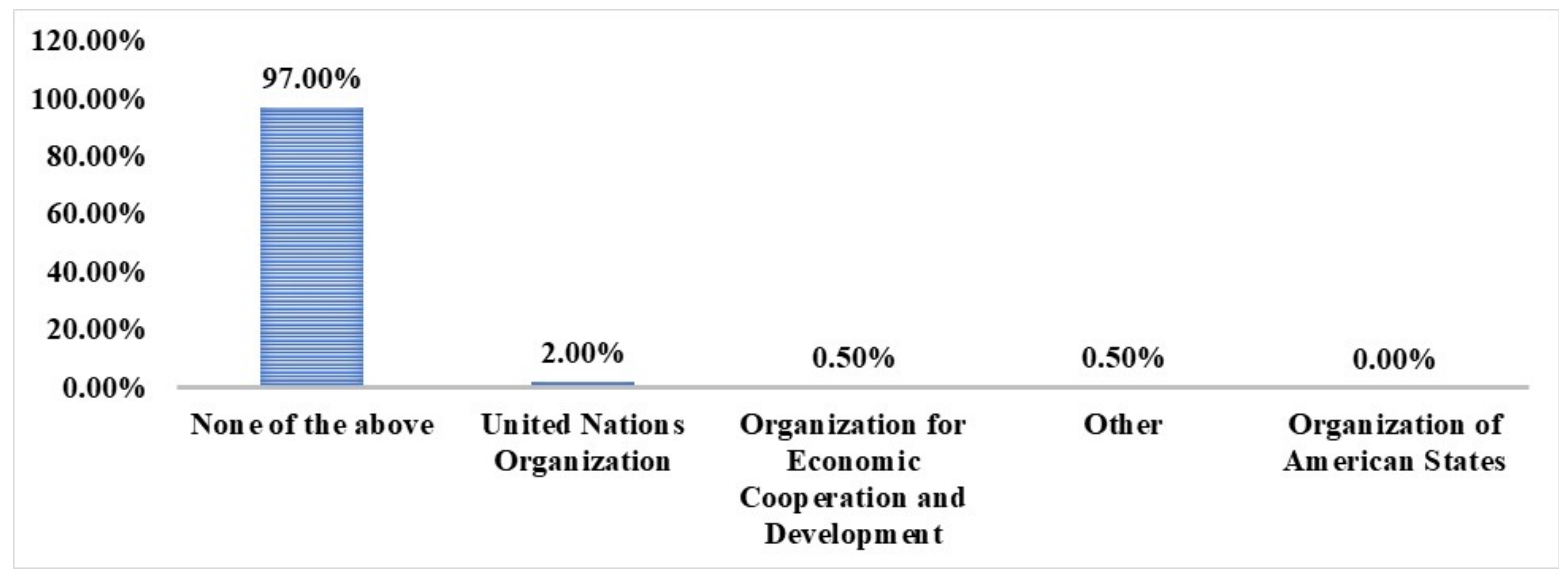

Source: Results of the application of the instrument to administrative staff at the hierarchical level of management or sub-direction (2017).

As you can see more than $95 \%$ of the municipalities do not consider for the elaboration of their plans, suggestions of international organizations for the incorporation of electronic government, for which they are subject exclusively to what the State and National plans dictate. 
Question 4. Within the Municipal Development Plan contemplate some axis / dimension / strategic objective related to the following options

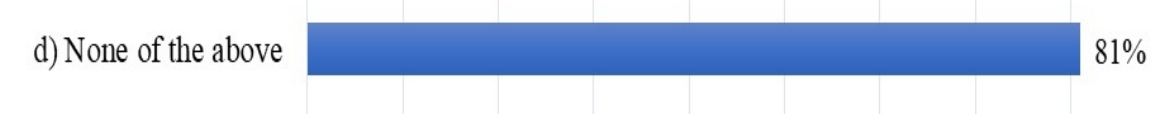

b) Information systems $\quad 8 \%$

c) Digital Government / Electronic Government $\quad 5 \%$

d) Open Government $4 \%$

a) Information Technologies $2 \%$

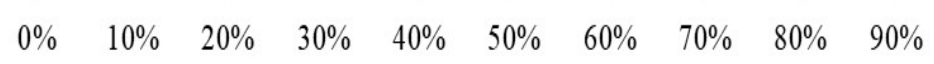

Source: Results of the application of the instrument to administrative staff at the hierarchical level of management or sub-direction (2017).

Comparing the results of this question, with Section A. of this section, there is a coincidence with $81 \%$ where electronic government is not considered as axis, dimension and objective within the municipal development plan. However, the other $10 \%$ is open to be considered in any other part of the municipal development plans under the concept of electronic government of the municipalities in question.

\section{PROPOSAL TO INCLUDE ELECTRONIC GOVERNMENT AS A TRANSVERSAL AXIS IN LOCAL DEVELOPMENT PLANS}

The proposal suggests that, as a transversal axis, all the plans contained in the Local Development Plan are accompanied by solutions where Information Technologies collaborate with the operational and administrative processes inside and outside the government. Taking into consideration the context of the municipalities (See Illustration 1) 


\section{Illustration 1. Alignment suggestion and context for the development of local development plans}

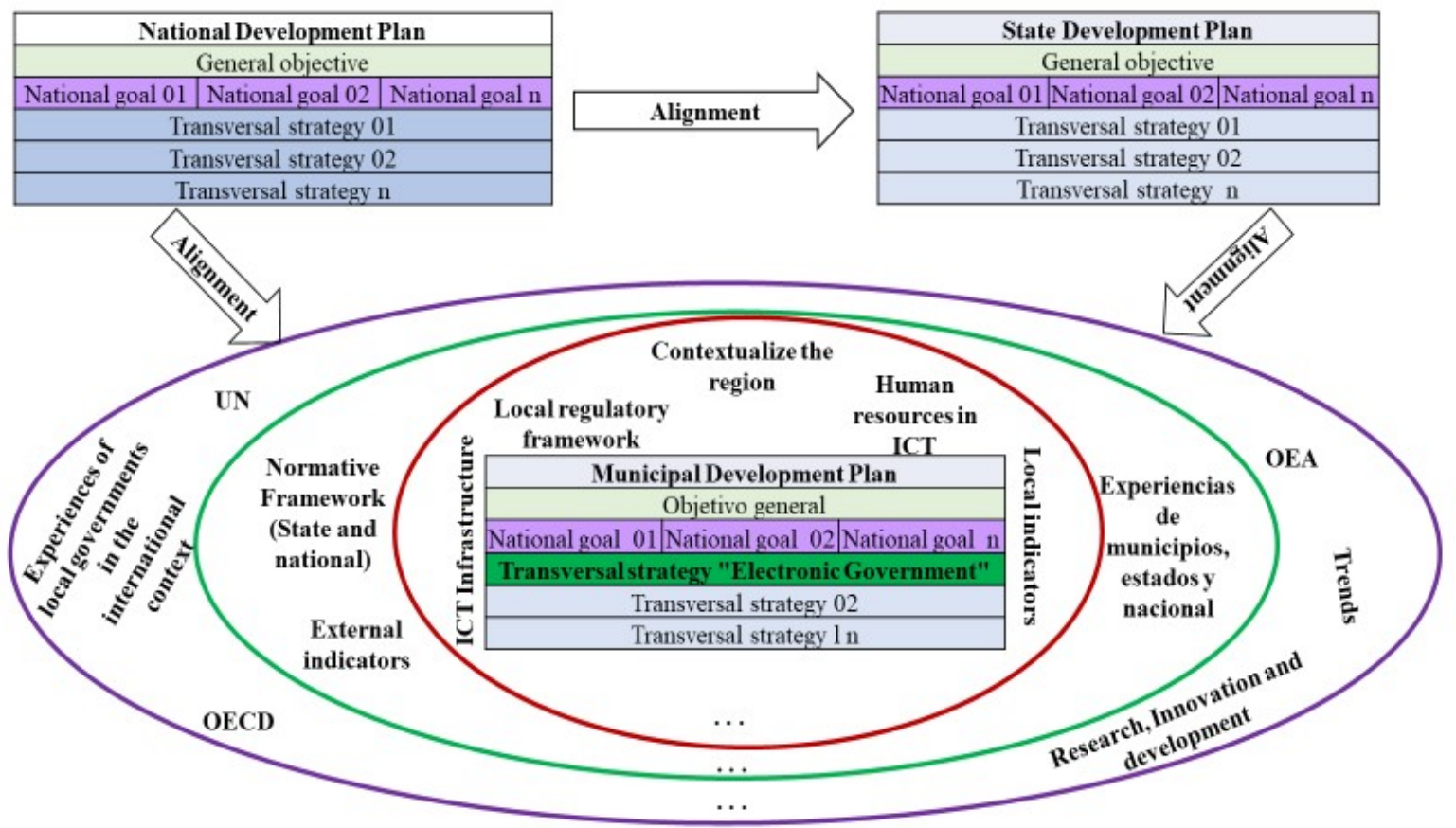

\section{Source: Own elaboration (2018), taking as reference the national plan, State and local development plans recent in the case of Mexico.}

As shown in Figure 1, the Local Development Plans (PDL) must be contextualized to the region, according to the regulatory framework that corresponds, and from that, analyze those internal and external variables that collaborate to carry out the execution satisfactory of the PDL, with a long-term vision, that transcends local government periods.

Derived from the above, it is suggested to establish a transversal axis and thirteen initial strategies (not limiting) which should be reviewed annually in order to enrich and allow its gradual evolution.

\section{Transverse axis. Electronic Government:}

Strategy 1: Analyze, design, develop and implement progressively Information Systems that allow reaching the connected level of evolution of electronic government

Strategy 2: Generate a long-term program in Information and Communication Technologies that transcends the three-year periods, with the aim of collaborating with future local administrations.

Strategy 3: Generate technological and regulatory mechanisms to allow interaction through information systems among the following actors: Government-Citizen, Government-Enterprise, Government-Employee, Government-Government

Strategy 4: Develop measurable government programs to progressively reduce the digital divide in all sectors of society.

Strategy 5. Carry out a search and analysis of Information and Communication Technology services that the local government can access in a safe and normatively permitted manner, for the optimization of its processes inside and outside the municipal government. 
Strategy 6: Progressively include indicators related to: online services organization index, telecommunications infrastructure index and human capital index

Strategy 7: Provide telecommunications infrastructure to all areas of local government in a progressive and strategic manner.

Strategy 8: Create an organizational structure for the support, development and evolution of electronic government.

Strategy 9: Analyze and generate a reengineering of administrative and operational processes aimed at interacting information among all areas of government, to facilitate and optimize processes and information through information systems.

Strategy 10: Ensure and base the processes of electronic government with the corresponding regulatory framework.

Strategy 11: Implement the security of information that ensures the information of all users, as well as the processes involved.

Strategy 12: Prepare information systems to adapt transparently to information systems of state and national governments, in the corresponding regulatory framework and framework.

Strategy 13: Generate for each area that integrates the municipal government, the organization manuals and their updates

\section{CONCLUSION}

Information and Communication Technologies are a collaborative tool with the activities of the human being, so the mechanisms for their use must be looked for, since their use brings multiple advantages, which will allow even the saving of material, economic resources, transparent processes, among others. Therefore, it is recommended that local governments include in their local development plans, the incorporation of electronic government, and generate mechanisms for their satisfactory implementation, monitoring and long-term evolution, where local administrations manage to continue the projects, analyze deviations and apply the corresponding corrections

\section{References}

F. Fernández, R. Nares y L. Garcia, Metodología de la investigación en ciencias sociales, México: Grupo Editorial Patria, 2008.

R. Hernández Sampieri, C. Fernández Collado y P. Baptista Lucio, Metodología de la investigación, (1ra. Ed.), Naucalpan de Juárez, Estado de México, México: McGRAW - HILL Interamericana de México, 1997.

Ruiz, Morales y Contreras, Perspectivas del gobierno electrónico local en México, Toluca: Universidad Autónoma del Estado de México, 2014.

United Nations, e-government survey 2016: e-government in support of sustainable development, New York: publicadministration, 2016.

P. C. M. y A. , «Analisis General del Gobierno Electrónico en México,» Revista de Tecnología y Sociedad, vol. 5, nº 9, 2016.

ONU, «United Nations e-government Survey 2014,» New York, ONU, 2014, p. 5.

INAFED, El plan municipal de desarrollo, México: SEIS, 2004.

Concepción de Buenos Aires, Plan de Desarrollo Municipal, Concepción, Argentina: Ayuntamiento del municipio de Concepción, 2015. 
Alcaldía de Cartagena de indias, Plan de desarrollo primero la gente 2016 - 2019, Cartagena de Indias, Colombia: Alcaldia Distrital de Cartagena, 2016.

Medellín, Plan de desarrollo Medellín 2016- 2019, Medellín, 2016.

Municipalidad de San José, Plan de Desarrollo Municipal 2017- 2020, San José, Costa Rica: Dirección de planificación estratégica institucional, 2017.

Government of Canada, Government of Canada Information Technology Strategic Plan 2016-2020, Ottawa, Canada: Government of Canada, 2018.

INEGI, «Finanzas públicas estatales y municipales,» 2015. [En línea]. Available:

http://www.beta.inegi.org.mx/proyectos/registros/economicas/finanzas/, recuperado 17/02/2018. 